\title{
Öğrenci Gözünden: Sosyal Bilgiler Dersini Ben Anlatsaydım
}

\author{
Aylin YAZICIOĞLU* \\ Vesile ALKAN $^{\dagger}$
}

$\ddot{O} z$

Öğrencilerin etkili, duyarlı ve bilinçli bir vatandaş olarak yetişmesinde sosyal bilgiler dersi önemli bir role sahiptir. Toplumsallaşma sürecine katılım, değerlerin ve becerilerin aktarılması bu dersin nasıl işlenmesi gerektiğini de ortaya koymaktadır. Bu bağlamda çalışma ilkokul öğrencilerinin sosyal bilgiler dersini yürüten öğretmen olarak dersi nasıl anlatmak istediklerini ortaya koymayı amaçlamıştır. Araştırma nitel yöntemde tasarlanmıştır. Üç farklı ilkokuldan seçilen öğrenciler, çalışma grubunu oluşturmuştur. Veri toplama aracı olarak yarı-yapılandırılmış form kullanılmıştır. Veriler 2015- 2016 eğitim-öğretim yılı bahar döneminde toplanmıştır. Elde edilen veriler, içerik analiz tekniğine uygun olarak analiz edilmiştir. Sosyal bilgiler dersinin anlatımıyla ilgili dokuz tema (eğlence, tartışma, hayal,...) ortaya çıkmıştır. Sosyal bilgiler dersinin anlatım yolunun gerekçesi ise altı temada (kalıcı, eğlence, katılım, ...) toplanmıştır. Diğer çalışmalarda sosyo-ekonomik düzey, öğretmen görüşü de dikkate alınarak daha detaylı bilgiler elde edilebilir.

Anahtar Kelimeler: Sosyal Bilgiler Dersi, Öğrenci Bakışı, Sosyal Bilgiler Öğretimi.

\section{From Pupils' Lenses: If I teach Social Studies}

\begin{abstract}
Abtsract
Social studies lesson has an important role in raising students as effective, sensitive and conscious citizens. Participation in the socialization process, transferring values and skills also reveals how this course should be taught. In this context, the study aimed to reveal how primary school students want to teach the lesson as the teacher conducting the social studies lesson. The research is designed in a qualitative method. Students selected from three different primary schools formed the study group. Semi-structured form was used as data collection tool. The data were collected in the spring semester of the 2015-2016 academicyear. The obtained data were analyzed in accordance with the content analysis technique. Nine themes (entertainment, discussion, fantasy,...) have emerged regarding the narration of the social studies lesson. The rationale for the way of teaching the social studies lesson is gathered under six themes (permanent, entertainment, participation, ...). In other studies, more detailed information can be obtained by taking into account the socio-economic level and teachers' opinion.
\end{abstract}

Key Words: Social Studies Lesson, Student View, Social Studies Education.

Geliş/Received: 17.10 .2020

Kabul/Accepted: 22.06.2021

*Etik Kurul İzni: Araştırmayla ilgili veriler 2020 yılı öncesinde (2015-2016 eğitim-öğretim yılı bahar dönemi) toplanmıştır. Bu nedenle etik kurul izni alınmamıştır.

\section{Giriş}

Yirmi birinci yüzyılın eğitim alanındaki getirilerine bakıldığında yirminci yüzyılın çok ötesinde olduğu ortadadır. Bu kapsamda yeni yüzyıl ile birlikte sınıf ortamındaki ihtiyaçlar da ciddi anlamda değişmiştir. Dolayısıyla öğrencilerin beklentisi ve öğretmenlerin rolü de yeni yüzyıl ile uyum göstermeye başlamıştır. Öğretmenlerin, öğrencilerin öğrenmesinde tek başına sorumluluklarının olmadığı gerçeğinden, öğrenme nasıl kolaylaştırabilir gerçeğine doğru ilerlemenin yaşandığı bu dönemde; öğrencinin, kendi öğrenme sürecini kontrol edebilmesi hedeflenmiştir.

\footnotetext{
*Karamanoğlu Mehmetbey Üniversitesi, Eğitim Fakültesi, Temel Eğitim Bölümü, e-mail: aylinyazicioglu20@ hotmail.com, ORCID: 0000-0003-3527-6982

†Pamukkale Üniversitesi, Eğitim Fakültesi, Temel Eğitim Bölümü, e-mail: vesile@ pau.edu.tr. ORCID: 0000-0002-8630-3357 (Makale türü: Araştırma makalesi)
} 
Öğrenme sürecinde hem akranlarıyla hem öğretmeni ile etkileşim halinde olması gereken öğrenci, sınıf ortamında artık Hodgkin'in (1998) belirttiği gibi 'pasifnesne' olmaktan çok 'aktif oyuncu' rolüne bürünmüştür. Öğrenme sürecinin etkinliği ve sürekliliği için bu aktifliğin devam etmesi gerekmektedir. $\mathrm{Bu}$ durum ister istemez öğrenciye öğrenme süreci hakkında deneyimlerini ve beklentilerini ifade etme firsatı yaratmalıdır. Dewey (1933); "Fikirlerin ve bilginin; duyguya, ilgiye ve isteme çevrilmediği bir eğitim yoktur" sözüyle de öğrencinin öğrenme-öğretme sürecinde önemsenmesi gerektiğini vurgulamıştır.

Rudduck ve Flutter (2004), öğrencinin öğrenme-öğretme sürecinde söz sahibi olmasının öğretmen-öğrenci ve içerik-öğrenci etkileşimine ciddi katkısı olduğunu belirtmişlerdir. Aynı şekilde Flutter (2007) öğrencinin kendini ifade edebilmesinin ve deneyimlerini paylaşabilmesinin; öğretmenin, öğrencinin nasıl daha iyi öğrenebileceğini bilmesine katkı sağlayacağını vurgulamıştır. Diğer taraftan Cook-Sather (2006) da öğrenme ve öğretme konusunda öğrencinin özgün bakış açısına sahip olduğunu söylemiştir. Dolayısıyla bu bakışın değerlendirilmesi gerekmektedir; çünkü öğrenciler sınıf ortamındaki paydaşlardandır ve kendi öğrenmesini değerlendirebilendir.

Alan yazın incelendiğinde; sosyal bilgiler dersi ile ilgili hatırı sayılır çalışmanın olduğu görülmektedir. $\mathrm{Bu}$ çalışmaların büyük çoğunluğu, sosyal bilgiler dersinin programının değerlendirmesini (Aykaç, 2007; Öztürk ve Kafadar, 2020) ve öğretmen görüşlerine göre sosyal bilgiler dersinin sorunlarını (Çelik ve Katılmış, 2010; Kuş ve Çelikkaya, 2010; Gömleksiz, Öner ve Özpolat, 2011; Memişoğlu ve Köylü, 2015; Gönenç ve Açıkalın, 2017) ve öğretimini (İskender, 2007; Şeker ve Yılmaz, 2011; Akpınar ve Kaymakçı 2012; Turan ve İbret, 2019) incelemiştir. Alandaki çalışmaların bir kısmının ise öğrenci görüşlerine dayalı olarak sosyal bilgiler dersinin öğretimine ve derse yönelik tutumlara (Akengin ve Demirsoy, 2011; Ocak ve Didin, 2018, Çakar ve Öner (2007) odaklandığ1 görülmektedir. Ulaşılan literatürde; ilkokul öğrencilerinin sosyal bilgiler dersinin öğretiminin nasıl olmasını beklediklerine ya da nasıl öğretilmesini istediklerine yönelik araştırmanın olmadığı fark edilmiştir.

Bu çalışma öğrencilerin öğretmen olduklarını hayal etmelerini düşünmelerini, sosyal bilgiler dersini nasıl anlatacaklarını ve bu dersin öğretilmesine ilişkin beklentilerini ve düşüncelerini belirlemeyi amaçlamıştır. Bir diğer yandan sosyal bilgiler dersinin öğretiminin nasıl olması gerektiğine ilişkin gerekçelendirmeler ile öğrencilerin hâlihazırda öğrenme sürecinde sorun olarak gördükleri durumların keşfedilmesini, ortaya çıkarılmasını sağlamaya çalışmıştır. Öğrencilere söz hakkının verilmesi ile birlikte hem alana yeni bir bakış açısının kazandırılması hem de öğretmenlerin sosyal bilgiler dersini yürütürken dikkat etmeleri gereken durumlar veya süreçte yapılması gereken değişikliklerin belirlenmesi ele alınmaya çalışılmıştır. Bu bağlamda araştırmanın temel problem cümlesi "Öğrenciler kendilerini sosyal bilgiler öğretmeni olarak düşündüklerinde derse nasıl bir işlerlik kazandırırdı" şeklinde ifade edilmiştir. Buna çerçevede çalışmanın alt problemleri ise;

- Öğrenciler kendilerini sosyal bilgiler öğretmeni olarak hayal ettiklerinde bu dersi nasıl anlatırdı?

- Öğrenciler anlatmayı düşündükleri dersi neden bu şekilde yürütürdü? şeklindedir. 


\section{Yöntem}

Çalışmanın desenlendirilmesinde nitel paradigma anlayışı kapsamında nitel araştırma yöntemi kullanılmıştır. Nitel araştırma; Bryman (2006) tarafından araştırılanın gözüyle bakılmasını sağlayarak en temel özelliğinin insanların olay, aksiyon, norm, değerlere yönelik bakış açılarının sunulması olarak tanımlanmıştır (s. 61). Çalışmada öğrencilerin öğretmen olduklarını hayal ettiklerinde sosyal bilgiler dersini nasıl anlatacakları ve neden bu yolu seçtiklerine ilişkin bir durumu ortaya çıarma amaçlı olarak nitel araştırma desenlerinden durum çalışması benimsenmiştir. Durum çalışmaları, bir durumun yaşandığı ortam içinde betimlenip detaylandırıldığı ve 'nasıl' ve 'ne için' sorularının cevaplandırıldığı çalışmalardır (Cohen, Manion ve Morrison, 2007; Yin, 2003).Dolayısıyla bu çalışmada ilkokul 4. sınıf öğrencilerinin kendilerini bir öğretmen olarak gördüklerinde sosyal bilgiler dersini nasıl anlatmak istediklerinin ve neden böyle bir yol tercih ettiklerine yönelik düşüncelerinin incelenmesi amaçlandığından çalışma nitel araştırma yöntem esaslarına uygun olarak tasarlanmış ve yürütülmüştür.

\section{Çalışma Grubu}

Araştırma grubunu, Denizli merkezde yer alan üç farklı ilkokulda öğrenim gören 126 dördüncü sınıf öğrencisi oluşturmaktadır. Çalışma okulları ile ilgili gerekli bilgiler, Denizli İl Milli Eğitim Müdürlügü’nden alınmıştır. Alınan bilgiler doğrultusunda; üst, orta ve alt sosyo-ekonomik düzeyde okulların öğrencilerinin çalışmada yer aldığı bilgisi edinilmiştir. Öğrencilerin farklı sosyo-ekonomik düzeydeki okullardan olmalarının sundukları görüşlerin çeşitliliğine katkı sağladığı analizler sırasında fark edilmiştir. Ancak bu farklılık, görüşlerin düzeylere göre kıyaslanması amacıyla analizler sırasında değerlendirilmemiştir dolayısıyla çalışma grubuna ait özellikler ve bulguların sunumunda düzeylere göre sınıflama yapılmamıştır. Çalışma grubuna ait öğrencilerin özellikleri Tablo 1'de sunulmuştur:

Tablo 1: Çalışma Grubuna Ait Kişisel Özellikler

\begin{tabular}{lcc}
\hline Öğrencilerin Özellikleri & F & $\%$ \\
\hline Cinsiyet & 56 & 55.5 \\
Kız & 70 & 45.5 \\
Erkek & & \\
Kardeş Sayısı & 22 & 17.5 \\
Yok & 72 & 57.1 \\
1 & 27 & 21.4 \\
2 & 5 & 4.0 \\
3+ & & \\
Anne Ĕgitim Durumu & 17 & 13.5 \\
İlkokul & 7 & 5.6 \\
Ortaokul & 42 & 33.3 \\
Lise & 60 & 47.6 \\
Üniversite ve üzeri & & \\
Baba Ĕgitim Durumu & 10 & 8.0 \\
İlkokul & 8 & \\
Ortaokul & 33 & 26.2 \\
Lise & 75 & 59.5 \\
Üniversite ve üzeri & & \\
Annenin Mesleği & 60 & 47.6 \\
Ev Hanımı & 15 & 12.0 \\
İşçi & 36 & 28.6 \\
Memur & 7 & 5.4 \\
Esnaf & 8 & \\
Diğer & & \\
\hline
\end{tabular}




\begin{tabular}{|c|c|c|}
\hline \multicolumn{3}{|l|}{ Babanın Mesleği } \\
\hline Çalışmıyor & 3 & 3.6 \\
\hline İşçi & 27 & 21.4 \\
\hline Memur & 42 & 33.3 \\
\hline Esnaf & 24 & 19.1 \\
\hline Diğer & 30 & 23.8 \\
\hline Toplam & 126 & 100 \\
\hline
\end{tabular}

Tablo 1'de yer aldığı gibi araştırma grubuna 126 öğrenci katılmıştır. Öğrencilerin 56'sı kız, 70’i ise erkektir. Öğrencilerden 22'sinin kardeşi yoktur, büyük çoğunluğu (72 kişi) tek kardeşe sahiptir. İki kardeşe sahip olan öğrenci sayısı 27, üç ve üçten fazla kardeş sayısı olanlar ise beştir). Anne eğitim durumuna bakıldığında; 60 anne üniversite ve üzeri,42'si ise lise mezunudur. Liseden alt düzeyde yer alan anne eğitim durumu ise 24'tür (17 ilkokul, yedi ortaokul). Baba eğitim durumuna bakıldığında; babaların 75'i üniversite ve üzeri mezunu, 33'ü lise mezunudur. Liseden alt düzeyde yer alan baba eğitim durumu sayısı 18'dir (10 ilkokul, sekiz ortaokul). Meslek durumları açısından ele alındığında, annelerin büyük çoğunluğu ev hanımıdır (60 kişi). Memur anne sayısı 36 ve işçi olan anne sayısı 15'tir. Esnaf ve diğer grupta yer alanların sayısı ise 15 'tir. Baba meslek durumuna bakıldığında 3 kişinin çalışmadığ 1 , memur olanların sayısının 42, işçi olanların sayısının 27, esnaf olanların 24, diğer grupta yer alanların ise 30 olduğu görülmektedir.

\section{Veri Toplama Araçları ve Verilerin Toplanması}

Çalışmada veri toplama araçları olarak öğrencilerin kişisel bilgilerinin yer aldığ bilgi formu ve görüşlerinin yer aldığı yarı yapılandırılmış form kullanılmıştır. Kişisel bilgi formunda cinsiyet, anne-baba eğitim durumu ve anne-baba meslek durumu bilgileri yer almıştır. Yarı yapılandırılmış formda ise öğrencilerin sosyal bilgiler öğretmeni olduğunu düşündüklerinde bu dersi nasıl anlatacaklarını ve nedenlerini belirtmelerini bulmaya dayalı sorular oluşturmuş̧tur. Çalışma verileri 2015- 2016 eğitim öğretim yılı bahar döneminde toplanmıştır. Verilerin toplanmasında hazırlık, pilot uygulama ve asıl uygulama aşamaları takip edilmiştir. Hazırlık aşamasında ilgili literatür taraması yapılmış, eserler incelenmiş, veri toplama araçlarının taslak halleri oluşturulmuştur. Pilot uygulama aşamasında uzmanlık alanı sosyal bilgiler öğretimi olan iki uzman hocanın görüşüne ve üç sınıf öğretmenine soruların anlaşılabilirliği ile ilgili başvurulmuş, bir ön çalışma gerçekleştirilmiştir. Assıl uygulama aşamasında ise geliştirilen veri toplama araçları öğrencilere uygulanmış, ardından verilerin analizi aşamasına geçilmiştir.

\section{Verilerin Analizi}

İlkokul 4. sınıf öğrencilerinin sosyal bilgiler öğretmeni olduklarını düşündüklerinde dersi nasıl anlatacakları ve neden böyle bir anlatım yoluna gidecekleri ile ilgili görüşlerini ortaya koymak ve açıklamak için içerik analiz tekniği kullanılmıştır. Yıldırım ve Şimşek (2011)'in belirttiği gibi; veriler içerik analizinde daha derin bir işleme tabi tutulur ve betimsel bir yaklaşımla fark edilmeyebilen kavram ve temalar içerik analizi sonucunda keşfedilebilir. Bu araştırmada da içerik analizi sürecinde, sözcükler ve cümleler organize edilmiş, bunlar arasındaki ilişkiler ise yorumlanarak ve yapılandırarak kategoriler 
oluşturulmuştur. Bu yapılandırma süreciyle öğrencilerden alınan görüşler daha anlaşılır hale getirilmeye çalışılmıştır. Çalışmanın güvenirliğini sağlamak amacıyla eş gözlemci yolu kullanılmıştır. Verilerin analizi sosyal bilgiler dersi çerçevesinde üç farklı ilkokulda öğrenim gören öğrencilerle ve görüşme sorularıyla sınırlı kalmıştır.

\section{Bulgular \\ Sosyal Bilgiler Dersinin Anlatımı}

İlkokul 4. sınıf öğrencilerinin sosyal bilgiler öğretmeni olduklarını hayal ettiklerinde bu dersi nasıl anlatmayı istediklerine yönelik görüşlerinin ele alındığı temalar ve frekans düzeyleri Tablo 1'de gösterilmiştir.

Tablo 1: Temalar ve Frekans Düzeyleri

\begin{tabular}{|cc} 
Temalar & Frekans Düzeyleri $(\boldsymbol{f})$ \\
\hline $\begin{array}{c}\text { Eğlenceli (Oyun, Tiyatro, } \\
\text { Resimle) Anlatma }\end{array}$ & 60 \\
$\begin{array}{c}\text { Tartışma-Fikir Almayla } \\
\text { Anlatma }\end{array}$ & 47 \\
$\begin{array}{c}\text { Etkinliklerle Anlatma } \\
\text { Iyi Hazırlanarak Açı-Net } \\
\text { Anlatma }\end{array}$ & 12 \\
$\begin{array}{c}\text { Gerçekçi (Hayata Yönelik) } \\
\text { Anlatma }\end{array}$ & 8 \\
Sunum Hazırlatarak Anlatma & 2 \\
Hayal Ettirerek Anlatma & 2 \\
Araştırma Yoluyla Anlatma & 2 \\
Beyin Yüklemesi Yoluyla \\
Anlatma \\
Toplam
\end{tabular}

Tablo 1'de görüldüğü gibi, ilkokul 4. sınıf öğrencilerinin bir öğretmen olarak hayallerinde sosyal bilgiler dersini nasıl anlatmayı düşündüklerine yönelik görüşleri, dokuz tema altında ele alınmıştır. Bu temalar; "Eğlenceli (Oyun, Tiyatro, Resimle) Anlatma", "Tartışma-Fikir Almayla Anlatma, "Etkinliklerle Anlatma", "İyi Hazırlanarak Açı- Net Anlatma", "Gerçekçi (Hayata Hazırlanarak) Anlatma, "Sunum Hazırlatarak Anlatma", "Hayal Ettirerek Anlatma", "Araştırma Yoluyla Anlatma" ve "Beyin Yüklemesi Yoluyla Anlatma" şeklindedir (Tabloda toplam frekans düzeyi, öğrenci sayısından daha fazla görünmektedir. Bu durum, bazı öğrencilerin belirttikleri görüşlerinin birden fazla temayla ilişkili olmasından kaynaklanmıştır)

"Eğlenceli (Oyun, Tiyatro, Resimle) Anlatma” temasıyla ilgili olarak bir öğrenci formda "Öncelikle Sosyal Bilgiler dersini çok sevdiğim için bu derste çok şeyler öğreneceğimizi çok eğleneceğimizi öğrencilere söylerdim. Onların bu ders hakkında ki düşüncelerini alırdım. Öğrencilerimle Sosyal Bilgiler dersine yönelik resimler yaparak ĕ̆lenerek dersimi işlerdim” (Ö21) şeklinde görüş belirtirken bir diğer öğrenci görüşünü "Bu dersi bir oyunmuş gibi anlatırdım. Mesela meslekler olsa sinıftaki ögrencilerden onları taklit etmelerini isterdim. Böylece öğrenciler hem eğlenmiş hem de ögrenmiş olurlar" (Ö24) şeklinde ifade etmiştir. Başka bir öğrenci ise, "Bu derste öğretmen olsaydım çocukları eğlendirerek anlatırdım. Fıkralar anlatırdım, tiyatrolar yapardım, eğitici ve bilgilendirici filmler izletirdim. Daha eğlenceli bir hale getirirdim" (Ö37) olarak görüşünü sunmuştur. 
Görüşünü belirten öğrenciler sosyal bilgiler dersinin eğitsel oyun, rol oynama, fikra ve filmler gibi materyal ve teknikler ile eğlenceli hale getirilerek anlatılmasından yana olduklarını belirtmişlerdir.

"Tartışma-Fikir Almayla Anlatma” temasına yönelik olarak bir öğrenci "Tartışmaya yönelik ve çocukların anlayabileceği gibi anlatırdım. Bunları şunun için yapardım. Çünkü herkesin fikrini söylemesini istediğim için” (Ö6) derken başka bir öğrenci “Derse girdiğimizde önce işleyeceğimiz konu ile ilgili bilgilendiririm. Sonra çocuklara sorular sorarım anlamadılarsa bir daha anlatırım. Onları tartıştırırdım, fikirlerini alırdım” (Ö17) demiştir. Diğer bir öğrenci ise "Disiplinli kuralcı ve öğretici anlatıp, tartıştırıp her öğrencinin derse katılmasını sağlardım, öğrencileri tartıştırarak sınıfın verimini arttırırdım” (Ö31) olarak görüşünü sunmuştur. Öğrencilerin düşünceleri doğrultusunda sosyal bilgiler dersinde tartı̧̧ma yöntemini kullanarak kendi öğrencilerinin hem fikirlerini rahatlıkla ifade etmelerini hem de etkin olmalarını sağlamayı amaçladıkları yönünde görüşlerinin olduğu görülmektedir.

“Etkinliklerle Anlatma” temasıyla ilgili görüşünü bir öğrenci “Öğrencilere etkinlikler verirdim. Bir sürü etkinliği birlikte yapardık. Sosyal Bilgiler dersiyle ilgili sorular sorarak, anketler hazırlatarak, sunumlar yaparak işlerdim” (Ö13) şeklinde açıklarken başka bir öğrenci "Etkinlikler yaparak anlatmaya çalışırdım. Mesela kesme yapıştırma gibi etkinlikler kullanırdım. Bu etkinlikleri öğrenciler daha iyi anlasınlar diye yapardım” (Ö90) şeklinde ifade etmiştir. Aynı şekilde diğer bir öğrenci ise "Etkinliklerle çocuklarımın anlayacă̆ı şekilde anlatırdım” (Ö107) şeklinde düşüncesini açıklamıştır. Görüşlerde de belirtildiği gibi öğrenciler etkin katılımını sağlayacak sınıf içi etkinlikleri tercih edeceklerini belirtmişlerdir.

"Iyi Hazırlanarak Açık-Net Anlatma” temasılyla ilgili bir öğrenci formda "Öğretmenimin anlattı̆̆ gibi bende öğrencilere açık net bir şekilde anlatırdım” (Ö81) olarak görüşünü dile getirmiş diğer bir öğrenci "Öğrencilerin anlaması için A'dan Z'ye kadar en ince noktalara değininceye kadar verirdim” (Ö110) demiştir. Başka bir öğrenci ise "Detaylı bir şekilde öğrencilerin anlaması için güzel güzel anlatırdım " (Ö126) olarak düşüncesini belirtmiştir. Görüşler doğrultusunda öğrenciler dersin açık, detaylı ve anlaşılır anlatılması yönünde görüşlerini belirtmişlerdir.

"Gerçekçi (Hayata Yönelik) Anlatma” temasına yönelik olarak bir öğrenci, "Bu aynı zamanda hayatımızda yapmamız gereken şeyleri anlattığı için gerçekçi bir şekilde anlatırdım.” (Ö1) başka bir öğrenci “Öğretmenimin anlattığ gibi gerçekçi net bir şekilde anlatırdım” (Ö81) olarak görüşlerini dile getirmişlerdir. "Sunum Hazırlatarak Anlatma” temasılyla ilgili olarak öğrenci “Öğrencilere sunumlar yaptırırdım. Dersi bu şekilde işlerdim” (Ö13), başka bir öğrenci “Öğrencilere slayt hazırlamalarını yapmalarını isteyerek, bilgisayar ya da elektronik aletlerden göstererek yardım alarak "(Ö16) șeklinde düşüncelerini açıklamışlardır. Gerçekçi anlatma ve sunum hazırlatarak anlatma temalarına ilişkin görüşler incelendiğinde bu öğrencilerin, öğrencilere sunum görevi verilmesini ve dersin özüne uygun olarak hayata uygun örneklendirmeler yapılmasını tercih ettikleri yönünde görüş bildirdikleri görülmektedir.

"Hayal Ettirerek Anlatma" temasıyla ilgili bir öğrenci formda "Öğrencilere hayal ettirerek, açıklayıcı cümlelerle anlatırdım” (Ö104) şeklinde, diğer bir öğrenci ise; “Öğrencilerin gözlerini 
kapattırıp onları düşündürürdüm” (Ö119) şeklinde görüşlerini ifade etmişlerdir. "Araştırma Yoluyla Anlatma" temasına yönelik olarak ise bir öğrenci "Öğrencilere araştırmalar yaptırarak, bu görevi vererek anlatırdım" (Ö5) derken; "Beyin Yüklemesi Yoluyla Anlatma” temasına ilişkin bir öğrenci "Beyin yüklemesi makinesi icat ederdim. O derste öğrencileri uyutur ve onların kafasına bu icadı takardım. Sırayla hepsinin beynine sosyal bilgilerin konularını yüklerdim” (Ö50) şeklinde görüşünü dile getirmiştir. Elde edilen sonuçlara göre öğrenciler hayal kurma, beyin kodlama ve araştırma yaptırarak dersi öğretme yoluna gideceklerini belirtmiştir.

\section{Sosyal Bilgiler Dersinin Anlatım Yolunun Gerekçesi}

Öğrencilerin sosyal bilgiler dersi öğretmeni olduklarını düşündüklerinde hayal ettikleri ders işleyişini neden böyle yürüttüklerine yönelik düşüncelerinin incelendiği temalar ve frekans düzeyleri ise tablo 2'de gösterilmiştir. Tablo 2'de toplam frekans düzeyinin öğrenci sayısından daha az sayıda olduğu görülmektedir. Bu durum, bazı öğrencilerin soruyu boş bırakması ya da soruya ilişkisiz cevapların verilmesi sonucu oluşmuştur; çünkü bu formlar, elenmiş ve analiz dışı tutulmuştur.

Tablo 2'de belirtildiği gibi 4. sınıf öğrencilerinin sosyal bilgiler dersini anlattıklarında neden böyle bir anlatım yolu seçtiklerine yönelik görüşleri altı farklı tema altında incelenmiştir. Bu temalar; “Öğrencinin Daha İyi Anlaması İçin (Kalıcılık)”, "Eğlenceli ve Kolay”, "Daha İyi Anlatmak İçin”, “Öğretmen Öyle Anlattı̆̆ İçin”, “íyi Bir Yöntem” ve “Katılımı Arttırmak” olarak ele alınmıştır.

Tablo 2: Temalar ve Frekans Düzeyleri

Temalar

Frekans Düzeyleri $(f)$

\begin{tabular}{|cc|}
\hline Öğrencinin Daha İyi Anlaması İçin & 52 \\
(Kalıcılık) & \\
Ĕglenceli ve Kolay & 48 \\
Daha İyi Anlatmak İçin & 9 \\
Öğretmen Öyle Anlattığı İçin & 5 \\
İyi Bir Yöntem & 1 \\
Katılımı Arttırmak & 1 \\
Toplam & 116 \\
\hline
\end{tabular}

Öğrencilerin sosyal bilgiler dersini anlattıklarını hayal ettiklerinde neden böyle bir anlatım yolu seçtiklerine yönelik görüşleri; “Öğrencinin Daha İyi Anlaması İçin (Kalıcılık)” temasına yönelik incelendiğinde bir öğrenci formda, "Çünkü ögrrencilerin bu şekilde daha rahat anlayacă̆ını düşünüyorum ve onların düşüncelerini anlamayı çok ama çok merak ederim” (Ö11) demiştir. Bir başka öğrenci ise "Çünkü ögrrencilerin kafasında daha kalıcı bir yer oluşturması için böyle bir yöntem uygulardım” (Ö22) şeklinde görüşünü ifade etmiştir. Öğrencilerin bildirdiği görüşlere göre, sosyal bilgiler dersinde bilginin kalıcı olması amacıyla anlatımların şekillendirilmesini düşündükleri ortaya çıkmıştır.

"Eğlenceli ve Kolay” temasıyla ilgili bir öğrenci “Çünkü çocukları eğlendirirsen onlar seni can kulağı ile dinlerler böylece öğrendikleri daha kalıcı olur” (Ö23) bir başka öğrenci “Çünkü eğlendirerek anlatırsam çocukların daha iyi aklında kalacağını düşünüyorum” (Ö37) diğer bir öğrenci ise "Çocuklar sıkıcı bir ders işlediğinde sıkılır ama ĕglenceli bir ders işlediklerinde daha iyi anlarlar” (Ö48) olarak 
görüşlerini belirtmişlerdir. Bu tema altındaki görüşler incelendiğinde; öğrencilerin dersin eğlenceli hale getirilmesi gerektiğine ve dersin kalıcılı̆̆ının öğrencilerin ilgilerini çekerek olacağına inandıkları görülmektedir.

"Daha İyi Anlatmak İ̧̧in” temasına yönelik olarak bir öğrenci formda "Dersi o şekilde daha iyi anlatabileceğimi düşünüyorum” (Ö8) derken "Çocukların daha iyi ögrrenmesi için bu şekilde anlatırım” (Ö105) şeklinde düşünce de belirtilmiştir. "Öğretmen Öyle Anlattı̆̆ İçin” temasılyla ilgili olarak bir öğrenci, "Çünkü ögrretmenimiz anlatma konusunda çok iyi ben de onun gibi ders anlatırdım” (Ö76) demiştir. Başka bir öğrenci ise "Zeki ve çevik olan öğretmenimiz daha bilgili olduğu için bende onun gibi ders anlatmayı seçerdim” (Ö118) şeklinde görüşünü açıklamıştır. Öğrencilerden elde edilen görüşlere göre öğrencilerin, dersin iyi anlaşılması ve kendilerine rol model seçtikleri öğretmenlerine benzemek amacıyla dersin anlatımını şekillendirecekleri görülmektedir.

“İyi Bir Yöntem” temasıyla ilgili olarak bir öğrenci "Bu yöntemi öğrencilerin anlaması için en uygun yöntem olarak görüyorum. Bu yöntem bana göre çok iyi bir yöntem” olarak görüşünü ifade etmiştir. "Katılımı Arttırmak" temasına yönelik olarak ise bir öğrenci "Öğrencilerin kafasında daha kalıcı bir yer oluşturması için bahsettiğim gibi anlatırdım” (Ö22) şeklinde düşüncesini açıklamıştır. Görüşlere göre, öğrencilerin, dersin daha iyi anlaşılması gerektiğine inandıkları görülmektedir. $\mathrm{Bu}$ yüzden seçecekleri anlatım şeklinde bu duruma dikkat edecekleri yönünde görüş bildirmişlerdir.

\section{Sonuç, Tartışma ve Öneriler}

Bu çalışma, ilkokul 4. sınıf öğrencilerinin deneyimlerine dayalı olarak sosyal bilgiler dersini nasıl anlatmak istediklerini ortaya çıkarmıştır. Çalışmanın birinci alt problem sonucu olarak dokuz tema ortaya çıkmıştır. 4. sınıf öğrencilerinin sosyal bilgiler dersi öğretmeni olduklarını düşündüklerinde dersi nasıl anlatacaklarına yönelik görüşlerine ilişkin temalar; eğlenceli (oyun, tiyatro, resimle) anlatma, tartışma-fikir almayla anlatma, etkinliklerle anlatma, iyi hazırlanarak açık-net anlatma, gerçekçi (hayata yönelik) anlatma, sunum hazırlatarak anlatma, hayal ettirerek anlatma, araştırma yoluyla anlatma, beyin yüklemesi yoluyla anlatma şeklinde oluşmuştur. Öğrenciler, öğretmen olmayı düşündüklerinde sosyal bilgiler dersini; eğlenceli bir şekilde, tartışarak, etkinlikler yoluyla, açık ve net, hayata- hayal ettirmeye dayalı, araştırma yoluyla anlatacaklarını, bu yollar dersi daha etkili ve verimli işleyeceklerini ifade etmişlerdir. Araştırmanın bu sonucu Özcan, Mirzeoğlu ve Çoknaz (2016), Zhu (2013), Yılmaz (2012), Çakar ve Öner (2007), Güven (2004) ve Aicinena’nın (1991) çalışmalarıyla benzerlik göstermektedir. İlgili araştırmalarda da öğrenciler derslerle ilgili beklentilerinde eğlenceli, heyecan verici, ilgi duyulması faktörlerini belirtmişlerdir. Öğrencilerin görüşlerinden yola çıkarak, sosyal bilgiler dersini farklı teknik ve materyal ile eğlenceli hale getirmek istedikleri, tartışma yöntemi ile öğrencilerin fikirlerini almayı hedefledikleri ve çeşitli sınıf içi etkinlikler ile öğrencilerin katılımını sağlamayı düşündükleri yönünde yorumlanabilir.

Çalışmanın ikinci alt problem olan öğrencilerin dersi işlediklerini hayal ettiklerinde neden böyle bir anlatım yolunu seçtikleri, sosyal bilgiler dersinin anlatım yolunun gerekçesi başlığı altında toplanmıştır. Bu başlık altında elde edilen veriler altı temada toplanmıştır. Bu temalar, öğrencinin daha 
iyi anlaması için (kalıcılık), eğlenceli ve kolay, daha iyi anlatmak için, öğretmen öyle anlattığı için, iyi bir yöntem ve katılımı arttırmak şeklindedir. Öğrencilerin öğretmen olduklarını hayal ettiklerinde sosyal bilgiler dersini anlatım yolu olarak tercih etme nedenlerine bakıldığında; kalıcılık sağlamaya çalıştıkları, dersi daha eğlenceli ve kolay olmasını amaçladıkları, daha verimli ve etkili bir anlatım sağlamaya çalıştıkları, katılımı arttırmak ve iyi bir yöntem sunmak amacını taşıdıkları sonucu elde edilmiştir. Bu sonuçların yanında öğretmeninin tarzını benimseyen ve devam ettirmek isteyen öğrenci görüşleri de dikkati çekmiştir. Öğrenciler belirttikleri nedenlerle sosyal bilgiler dersini daha etkili, yararlı ve verimli işleyeceklerini ifade etmişlerdir. Çalışmadan edinilen bulgular Özcan, Mirzeoğlu ve Çoknaz (2016), Zhu (2013), Yılmaz (2012), Çakar ve Öner (2007), Güven (2004) ve Aicinena'nın (1991) araştırmalarıyla da örtüşmektedir. İlgili araştırmalarda da öğrenciler derslerin yürütülme sürecinde eğlence, dikkat çekici ve heyecan etkenlerini vurgulamışlardır. İlgili sonuçlarla birlikte öğrencilerin sosyal bilgiler dersinde öğrenilenlerin kalıcılığının sağlanması gerektiğine inandıkları, dersin eğlenceli bir şekilde ve kolaylaştırılarak anlatılmasının da öğrenmede kalıcılığını sağlayacağını düşündükleri şeklinde yorumlanabilir.

Elde edilen sonuçlara göre sosyal bilgiler dersinde öğretmenler tarafindan uygulanan etkinliklerin çalışma grubundaki öğrencilerin görüşlerini etkilediği söylenebilir. Sonuçlara göre aynı etkinliğin öğrencilerin bazılarında olumlu etki bıraktığı; bazılarında ise bunun biraz daha gelişmesi gerekir şeklinde alg1 yaratabildiği görülmektedir. Örneğin, bazı öğrenciler, kendilerini öğretmen gibi düşündüklerinde tartışma etkinliklerinde öğrencilerin fikirlerini daha rahat ve daha fazla söylemesi gerekir vurgusunu yapmışlardır. Ancak bir grup öğrenci de tartışma yöntemini öğretmenleri gibi kurallarına göre yapmaları gerektiğini, böylece sınıf kontrolünün sağlanabileceğini ya da daha iyi öğrenilebileceğini belirtmişlerdir. Bu durum öğrencilerin dersin öğretimi ile ilgili beklentileri ile alakalı olabilir.

Yine çalışma sonuçlarına göre öğrencilerin sosyal bilgiler dersini öğretirken tercih etmeyi düşündükleri öğretim yöntem veya tekniğin eğlenceli ve kolay uygulanabilir olmasına vurgu yaptıkları görülmektedir. Aynı şekilde bu yöntem ve tekniklerin kendi öğrencilerinin daha iyi anlamalarını sağlaması gerektiğine inandıklanı da görülmektedir. Sosyal bilgiler dersinde kendi öğrencilerinin sıkılmaması gerektiği vurgusunu yapan öğrencilerin görüşlerinin deneyimlerinden etkilendiği söylenebilir. Bazı öğrencilerin ders eğlenceli olursa öğrenci sıkılmaz ve daha iyi anlar gibi görüşleri, kendi yaşadıkları durumlardan dolayı beklentilerini dile getiren örnek olabilir. Diğer taraftan öğretmenlerinin de kullandığı şekilde anlatım olarak belirttikleri görüşleri de olumlu deneyimlerine örnek olabilir.

Cook-Sather (2006), öğrencilerin kendi eğitimlerini şekillendirebilmeleri için onlara firsat verilmesi gerektiğini vurgulamıştır. Bu çalışmada alandaki çalışmalardan farklı olarak ilkokul ögrencilerine söz hakkı verilerek onların sosyal bilgiler dersini nasıl anlatmak istediklerini ve neden böyle anlatmak istediklerini ortaya çıkarmak amaçlanmıştır. Elde edilen sonuçlar ile öğrencilerin sosyal bilgiler dersinin öğretimi ile ilgili deneyimleri ve beklentileri ortaya çıkarılmaya çalışılmıştır. Böylece 
öğrencilerin gözünden bir yandan sosyal bilgiler dersinin öğretimi nasıl olmalı sorusuna cevap bulunmuş bir yandan öğretmenler için öneriler oluşturulmaya çalışılımıştır.

Araştırma öğrencilerin sosyal bilgiler dersi öğretmeni olduklarını düşündüklerinde bu dersi nasıl anlatmak istedikleri ve neden bu yolu tercih ettikleri ile sınırlı kalmıştır. Bundan sonra yapılacak çalışmalarla ilgili olarak benzer çalışmanın farklı derslerle birlikte yürütülmesi önerilebilir. Örneğin; fen bilgisi, matematik, hayat bilgisi vs. gibi derslerde öğrencilerin öğretmen olduklarında dersi nasıl anlatmayı istedikleri ve neden böyle bir yol izledikleri ile ilgili görüşleri alınabilir. Böylelikle bu derslerin öğrenci gözüyle değerlendirilmesi öğrencilerin öğretmen olduklarını hayal ettiklerinde beklenti ve görüşleri ele alınabilir. Benzer nitelikte gerçekleştirilecek çalışmalar daha geniş öğrenci gruplarıyla birlikte ele alınarak değerlendirilebilir. Araştırma nitel araştırma çerçevesinde ele alınmıştır yapılacak çalışmalarda farklı yöntemler kullanılabilir. Nicel ya da karma yöntemlerde nasıl sonuçlar elde edilecek incelenebilir. Örneğin; ölçek geliştirilerek geniş çaplı öğrenci gruplarıyla çeşitli değişkenler de göz önünde bulundurularak ele alınabilir ya da veri toplama araçları farklılaştırılarak değerlendirilebilir. Öğrenci ya da öğretmenle birlikte çalışılarak sınıfın öğrencileri ve öğretmeniyle dersin işlenişiyle ilgili, dersin öğrenci gözüyle nasıl hayal edildiği öğretmen gözüyle nasıl karşıllık bulduğu incelenebilir.

Yazar Katkıları: Yazarların her ikisi de makaleye eşit oranda katkı sağlamıştır.

Çıkar Beyanı: “Öğrenci Gözünden: Sosyal Bilgiler Dersini Ben Anlatsaydım” isimli makalemiz ile ilgili herhangi bir kurum, kuruluş, kişi ile mali çıkar çatışması yoktur ve yazarlar arasında çıkar çatışması bulunmamaktadır.

Teşekkür: Çalışma verilerinin toplanmasında belirtilen üç ilkokulun dördüncü sınıf öğrencilerine ve sınıf öğretmenlerine araştırmamıza gösterdikleri katkı ve özveriden dolayı teşekkürlerimizi sunmayı borç biliriz.

\section{Kaynakça}

Aicinena, S. (1991). The teacher and student attitudes to wards physical education. The Physical Educator, 48 (1), 28-32.

Akpınar, M. ve Kaymakçı, S. (2012). Ülkemizde sosyal bilgiler öğretiminin genel amaçlarına karşılaştırmalı bir bakış. Kastamonu Eğitim Dergisi, 20 (2), 605-626.

Akengin, H. ve Demirsoy, M. (2011). Dördüncü ve beşinci sınıf öğrencilerinin sosyal bilgiler dersine ilişkin görüşleri. M.Ü. Atatürk Eğitim Fakültesi Eğitim Bilimleri Dergisi, 33, 5-23.

Aykaç, N. (2007). İlköğretim sosyal bilgiler dersi eğitim-öğretim programına yönelik öğretmen görüşleri. Elektronik Sosyal Bilimler Dergisi, 6(22), 46-73.

Bryman, A. (2006). Quantity and quality in social research. London and New York: Routledge. 
Cohen, L.,Manion, L. ve Morrison, K. (2007). Research methods in education. (6. Baskı). Oxon: Routledge.

Cook-Sather, A. (2006). Sound, presence, andpower: "Studentvoice" in educational research and reform. Curriculum Inquiry, 36(4), 359-390.

Çakar, Ö. ve Öner, Ü. (2007, Eylül 5-7). Etkili bir sosyal bilgiler ögretimi için ögrrenci gözüyle ögretmenden beklentiler (Sözlü Sunum).XI. Ulusal Eğitim Bilimleri Kongresi, Tokat, Türkiye.

Çelik, H. ve Katılmış, A. (2010). Sosyal bilgiler öğretmenlerinin derslerindeki öğrenci başarısını etkileyen unsurlara ilişkin görüşleri. Marmara Coğrafya Dergisi, 22, 128-153.

Dewey, J. (1933). How we think: A restatement of therelation of reflective thinking to the educative process. Boston, MA: Heath.

Flutter, J. (2007). Teacher development and pupil voice. Curriculum Journal, 18 (3), 343-354.

Gömleksiz, M. , N. , Öner, Ü. ve Bozpolat, E. (2011). Sınıf öğretmenlerinin sosyal bilgiler derslerini yürütmelerine ilişkin görüşlerinin değerlendirilmesi. İlköğretim Online, 10(3), 872-893.

Gönenç, S. veAçıkalın, M. (2017). Sosyal bilgiler öğretmenlerinin sosyal bilgiler öğretiminde karş1laşt1kları sorunlar ve bunlara getirdikleri çözüm önerileri. Trakya Üniversitesi Ĕgitim Fakültesi Dergisi, 7(1), 26-41.

Güven, İ. (2004). Etkili bir öğretim için öğretmenden beklenenler. Milli Eğitim Dergisi, S: 164. Güz.

Hodgkin, R. (1998) Partnership with Pupils, Children UK, Summer.

İskender, P. (2007). İlköğretim okullarında sosyal bilgiler öğretiminin öncelikleri ve sosyal bilgiler öğretmeni yetiştirmeye yönelik çıkarımlar. Ahi Evran Üniversitesi Kırşehir Eğitim Fakültesi Dergisi (KEFAD), 8(1), 21-29.

Kuş, Z. ve Çelikkaya, T. (2010). Sosyal bilgiler öğretimi için sosyal bilgiler öğretmenlerinin beklentileri. Yüzüncü Y1l Üniversitesi Eğitim Fakültesi Dergisi, 7 (2), 69-71

Memişoğlu, H. ve Köylü, G. (2015). Sosyal bilgiler dersindeki sorunlar ve çözüm yollarına ilişkin sosyal bilgiler öğretmenlerinin görüşleri. Turkish Studies, 10 (11), 1099-1120.

Ocak, G. ve Didin, M. (2018). Öğrencilerin yapılandırmacı sosyal bilgiler öğrenme öğretme sürecine yönelik görüşleri ile sosyal bilgiler dersine yönelik tutumları arasındaki ilişki. Karaelmas Journal of Educational Sciences, 6, 1-14.

Özcan, G., Mirzeoğlu A.D. ve Çoknaz, D. (2016). Öğrenci gözüyle beden eğitimi ve spor dersi ve öğretmeni. Abant İzzet Baysal Üniversitesi Eğitim Fakültesi Dergisi, 16 (1), 270-291.

Öztürk, C. ve Kafadar, T. (2020). Sosyal bilgiler dersi programının değerlendirilmesi. Trakya Eğitim Dergisi, 10(1), 134-148.

Rudduck, J., ve Flutter, J. (2004). How to improv eyour school: Giving pupils a voice. London: Continuum.

Şeker, M. ve Yılmaz, K. (2011). Sosyal bilgiler öğretiminde öğrenme stillerinin kullanılmasının öğrencilerin öğrenme düzeyleri üzerindeki etkisinin incelenmesi. Kastamonu Eğitim Dergisi, 19 (1), 251-266.

Turan, S. ve İbret, B. Ü. (2019). Teachers' opinions on the teaching of spatial citizenship in social studies (Sosyal bilgiler dersinde mekânsal vatandaşlığın öğretimine ilişkin öğretmen görüssleri).International Journal of Geography and Geography Education (IGGE), 40, 59-78.

Yıldırım, A. ve Şimşek, H. (2011). Sosyal bilimlerde nitel araştırma yöntemleri (8. Baskı). Ankara: Seçkin Yayıncılık. 
Öğrenci Gözünden: Sosyal Bilgiler Dersini Ben Anlatsaydım

Yılmaz, A. (2012). Ortaöğretim kurumlarındaki yönetici, beden eğitimi öğretmeni ve öğrencilerin beden eğitimi dersine ilişkin görüşlerinin tespit edilmesi: Nitel bir çalışma. Yayımlanmamış Yüksek Lisans Tezi. Karadeniz Teknik Üniversitesi, Eğitim Bilimleri Enstitüsü, Trabzon.

Yin, R. K. (1993). Applications of Case Study Research. Beverly Hills. CA, Sage Publications.

Zhu, X. (2013). Exploring students' conception and expectations of achievement in physical education. Measurement in Physical Education and ExerciseScience,17, 62-73. 